\title{
EFFECT OF SOME CHEMICAL MUTAGENS ON MORPHOLOGICAL CHARACTERS AND CORM PRODUCTIVITY OF SOME GLADIOLUS SP. CULTIVARS
}

\author{
H.F. El-Tayeb
}

Botanical Gardens Res. Dept., Hort. Res. Inst., Alex., Egypt.

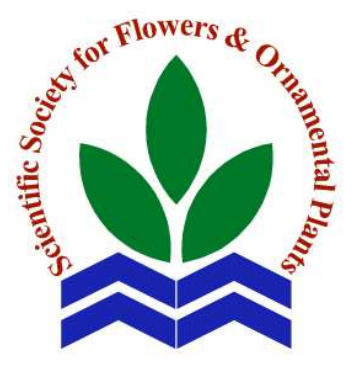

Scientific J. Flowers \& Ornamental Plants, 1(1):45-53 (2014).

Received:

$4 / 2 / 2014$

Revised by:

Prof. Dr. T.M. Abou Dahab. Cairo Univ.

Prof Dr. G.A. Ibrahem, Hort. Res. Inst., ARC.
ABSTRACT: Two pot experiments were carried out at the Nursery of Antoniades Botanical Garden, Hort. Res. Inst., Alexandria, Egypt during the years of 2012 and 2013. The objectives of this study were to study the effect of soaking corms of three cultivars of Gladiolus sp., namely: Eurovision (Red), Nova Lux (Yellow) and Peter Pears (Peach) in the aqueous solution of either ethyl methane sulfonate (EMS) at the rates of $0,0.1,0.2,0.3$ and $0.4 \%$ concentrations for $24 \mathrm{hrs}$. or colchicine at the rates of 0 and $0.1 \%$ concentrations for 24 or $48 \mathrm{hrs}$. on growth performance and corm production.

The obtained results indicated that the different levels of EMS had a slight effect on sprouting date, but colchicine treatments induced a significant earliness in both seasons, with the dominance of soaking for 24 hrs. treatment. Cultivar factor had no pronounced effect on sprouting date. All treatments increased plant height over control, but the tallest plants were obtained from corms soaked in EMS at 0.1 or $0.2 \%$ concentrations. Plants of cv. Peter Pears were generally taller than those of Eurovision and Nova Lux cultivars. The greatest No. leaves/plant were recorded in the two seasons by soaking the corms in $0.1 \%$ colchicine solution for $24 \mathrm{hrs}$. Furthermore, soaking in $0.1 \%$ colchicine solution for $48 \mathrm{hrs}$. and in EMS one up to $0.3 \%$ level recorded also a higher No. leaves. Eurovision and Nova Lux cvs. gave higher No. Leaves than cv. Peter Pears in both seasons. However, the greatest No. Leaves/plant for the 3 used cultivars in both seasons were also attributed to treating with $0.1 \%$ colchicine solution for $24 \mathrm{hrs}$. Colchicine at $0.1 \%$ for $24 \mathrm{hrs}$. resulted the widest diameter and heaviest fresh weight of the new formed corms, as well as the highest number of cormels/plant over control and other treatments in most cases of the two seasons. The highest No. cormels/plant in the two seasons were recorded for Eurovision and Nova Lux cvs. also by soaking in $0.1 \%$ colchicine solution for $24 \mathrm{hrs}$., but for cv. Peter Pears that was gained by soaking in $0.1 \%$ EMS solution for $24 \mathrm{hrs}$.

Therefore the study recommended to soak the corms of the three studied cultivars in $0.1 \%$ colchicine solution for $24 \mathrm{hrs}$. immediately before planting to get better growth performance and higher corm production.

Key words: Gladiolus - Ethyl methane sulfonate (EMS) - colchicine corm production. 


\section{H.F. El-Tayeb}

\section{INTRODUCTION}

Gladiolus sp. L., corn flag or sword lily (Fam. Iridaceae) is one of the most important commercial cut flowers all over the world.

Chemical mutagens are used for induction mutations, as they usually give excellent and secure results. Ethyl methane sulfonate (EMS) is an organic compound. It is a mutagenic, teratogenic, and possibly carcinogenic. It produces random mutations in genetic material by nucleotide substitution; particularly by guanine alkylation. This typically produces only point mutations (Wikipedia, 2013).

In this regard, Misra and Bajpai (1983) on 9 cultivars of gladiolus, found that treating corms with Ethyl methane sulfonate (EMS), diethyl sulfonate (DES) or methyl nitroso urea (MNU) decreased corm production in some cultivars compared to the control, but increased it in other ones. On Gerbera, Schiva et al. (1984) revealed that using EMS at low concentration (0.1\%) and for short time recovered large M2 population with a good rate of non-lethal mutations. Besides, Berenschot et al. (2008) mentioned that EMS at the rates of $0.05,0.1,0.15,0.2$ and $0.25 \%$ caused developmental defects and decreased seedling viability in petunia plants obtained from the mutagenized seeds. High doses of EMS reduced the number of plants with primary leaves at 15 days after sowing by about $44 \%$ and decreased survival rate to $28 \%$ comparing with control. Similar observations were obtained by kannan et al. (2002) on Jasminum sambac, Latado et al. (2004) and Padmadevi and Jawaharlal (2011) on chrysanthemums, Dhakshana et al. (2010) on Jatropha curcas Yi and Traore (2011) who reported that exposure leaf sections of Saintpaulia cv. Crystopal to EMS at the rate of $0.2,0.4$ and $0.6 \%$ for $30,60,120$ or 240 minutes recovered adventitious shoots from the treated explants. Shoots producing at least 6 leaves were induced to root and the resulted plantlets were successfully transplanted to the soil.
Colchicine is a highly poisonous alkaloid, originally extracted from plants of genus colchicum, especially $C$. autumnale (also known as the Meadow saffron) and from corms of Gloriosa spp. It has a medicinal use to treat rheumatic complaints, especially gout. It was also used for inducing polyploidy in plant cells by inhibiting chromosome segregation during meiosis (Wikipedia, 2014). Subjecting the plants to various concentrations of colchicine for different durations exhibited a marked fluctuation in the morphogenetic characters. In this concern, El-Meligy (1981) declared that soaking corms of gladiolus cv. Eurovision in colchicine solution (200 ppm) for 6 hours increased the number and weight of cormels. Endo et al. (1997) observed that treated shoot tips of chrysanthemum with colchicine at the rate of $0.2 \%$ for either 24 or 48 hrs. resulted doubled chromosome plants which were obviously dwarfed with less number of branches, leaves and flower buds. On Asiatic hybrid lily "Connecticut king", Han et al. (1999) pointed out that increasing level and duration of colchicine treatment decreased survival rate and shoot regeneration.

On the same trend, Silva et al. (2000) on the proto corm-like bodies of Cattleya intermedia, Youssef (2003) on Yucca elephantips and philodendron scandens, Sayed et al. (2007) on Solidago altissima var. "Tara", Wu et al. (2007) on Oriental lilium cultivars "Con. Amore" and "Acapulco" and Xing et al. (2011) who noted that subjecting seeds of Catharanthus roseus to $0.2 \%$ colchicine solution for $24 \mathrm{hrs}$. gave the highest percent of tetraploid plants which had larger stoma and more branches and leaves comparing with the control. Wang and Lei (2012) claimed that immature embryos of Clivia miniata treated with 0.01 or $0.03 \%$ colchicine gave tetraploids had thicker, wider, shorter, rougher and deepercolorful leaves, fewer roots and slower growth than diploids.

This work aimed to study the effect of both EMS and colchicine at different 
concentrations on morphological and corm production in some gladiolus commercial cultivars (Eurovision (Red), Nova Lux (Yellow) and Peter Pears (Peach)).

\section{MATERIALS AND METHODS}

Two pot experiments were consummated at the Nursery of Antoniades Botanical Garden, Hort. Res. Inst., Alexandria, Egypt during the two consecutive seasons of 2012 and 2013 to explore the effect of both Ethyl methane sulfonate (EMS) and colchicine at various levels and soaking duration on vegetative growth and corm production of three cultivars of gladiolus.

Therefore, corms of three cultivars of Gladiolus sp., namely: Eurovision (Red), Nova Lux (Yellow) and Peter Pears (Peach) at the size and weight ranged between 4-6 $\mathrm{cm}$ diameter and 40-50g, respectively for the three cultivars. The corms were dipped before planting in a fungicide solution of $0.25 \%$ orthocide for 20 minutes, and soaked in an aqueous solution of one of the following chemical mutagens:

1- Ethyl methane sulfonate (EMS), a commercial product of methane sulfonic acid ethyl (obtained from El-Gomhoria Co., Alex. branch) at the rates of 0.1, 0.2, $0.3,0.4 \%$ for 24 hours.

2- Colchicine, an alkaloid product (obtained from El-Gomhoria Co., Alex branch) at the rates of $0.1 \%$ for either 24 or 48 hours.

3- Corms of control treatment were soaked in tap water for 24 hours.

Immediately after soaking, the treated corms were planted on $15^{\text {th }}$ of October for each season in 20-cm-diameter clay pots filled with about $2.5 \mathrm{~kg}$ of mixture of clay and sand $(3: 1, \mathrm{v} / \mathrm{v})$ at a depth of $5 \mathrm{~cm}$ from soil surface (one corm/pot).

The experiments were set out in a complete randomized block design (Mead et al., 1993) with factorial concept, as each treatment was replicated three times. Each replicate contained 5 corms. Irrigation and agriculture practices were done whenever needed. The fertilization, however was carried out after one month from planting and repeated again one month later with the rate of $3 \mathrm{~g} /$ pot of kristalon fertilizer (19:19:19 + micronutrients, manufactured by DSM Agrospecialists, Holland) as a soil drench.

\section{Data recorded:}

The mean number of days from planting to sprouting (days), plant height $(\mathrm{cm})$ from the soil surface to the terminal top of plant and the mean number of leaves/plant were recorded before flowering. After flowering, however the new corm and cormels were lifted and cleaned to measure the following: new corm diameter $(\mathrm{cm})$ and its fresh weight (g), as well as the average number of cormels/plant.

Data were then tabulated and statistically analyzed according to SAS Institute Program (1994) using Duncan's multiple range test (Duncan, 1955) to verify the significant difference between means of various treatments.

\section{RESULTS AND DISCUSSION}

Effect of some chemical mutagens and some Gladiolus sp. cultivars on:

\section{1- Vegetative growth:}

Data averaged in Table (1) revealed that the different levels of EMS had a slight effect on sprouting date of gladiolus corms with non-significant differences as compared to control in the two seasons, except for the concentration of $0.2 \%$ which caused a significant precocity in this character in the second season only. Concerning the effect of colchicine treatments, a significant earliness was obtained in both seasons. Soaking the corms in colchicine for $24 \mathrm{hrs}$. recorded the least number of days from planting to sprouting in the two seasons (13.55 and 13.53 days against 15.14 and 15.82 days for control in the first and second seasons, respectively). Cultivar factor had no effect on such character in both seasons. However, the least number of days from planting to sprouting was attained by $0.1 \%$ colchinine treatment for $24 \mathrm{hrs}$. with cv. Nova Lux in the 
H.F. El-Tayeb

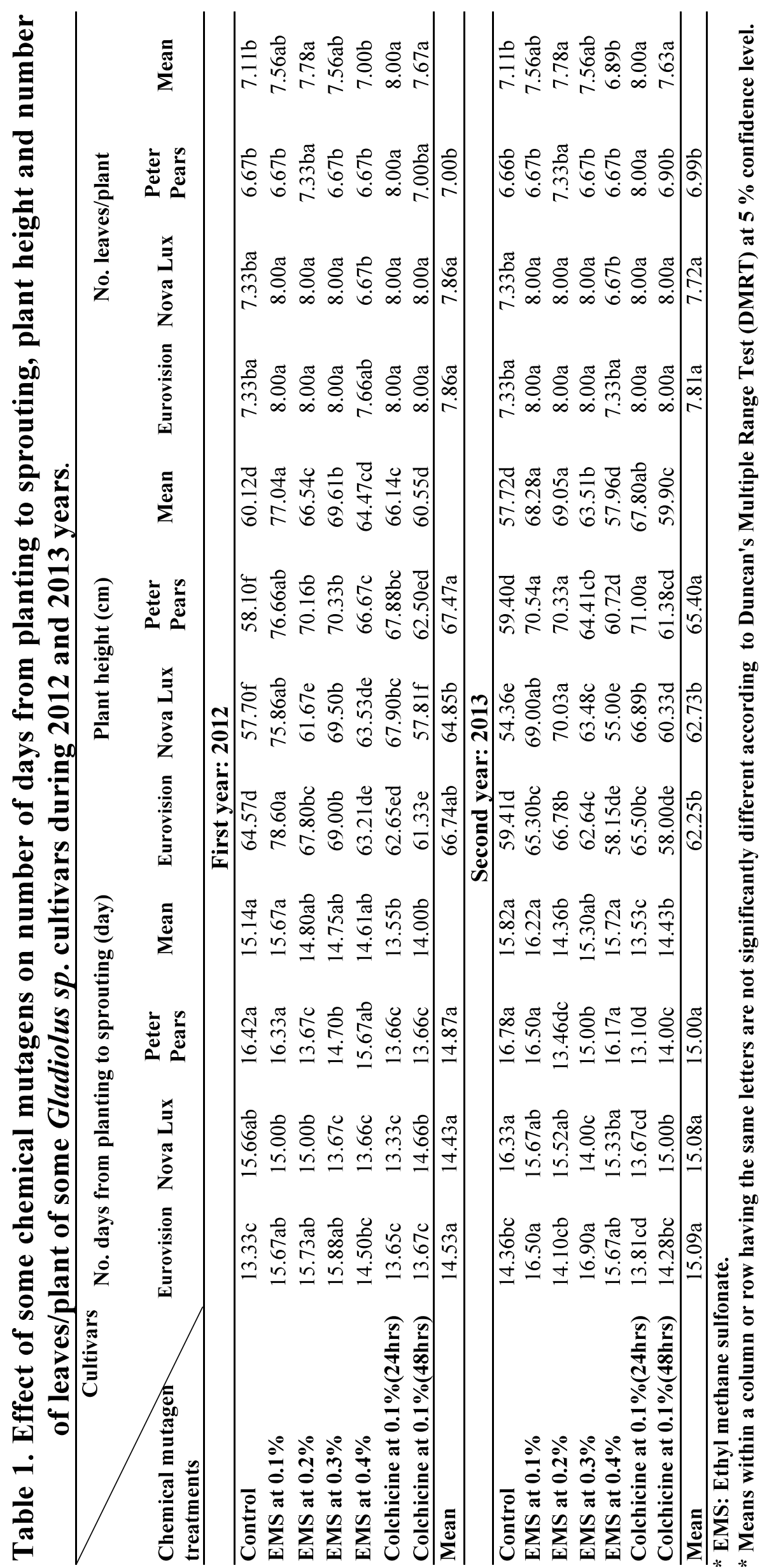


$1^{\text {st }}$ season (13.33 days) and with cv. Peter Pears in the $2^{\text {nd }}$ one (13.10 days).

As for plant height $(\mathrm{cm})$, data in Table (1) showed that all treatments increased this parameter over control with various significance levels in the two seasons, but the tallest plants were obtained from corms soaked in EMS at $0.1 \%$ concentration in the first season and those soaked in EMS at either 0.1 or $0.2 \%$ concentration in the second one. Concerning the effect of cultivars, cv. Peter Pears plants were taller than those of the other two cultivars in the two seasons. Results of interactions indicated that the tallest plants in the first season were scored by cv. Eurovision corms treated with $0.1 \%$ EMS solution $(78.6 \mathrm{~cm})$ and followed by corms of Peter Pears and Nova Lux cultivars treated with the same treatment, while in the second one, that was attained by Peter Pears cultivar corms subjected to colchicine at $0.1 \%$ for 24 hours and followed by plants of the same cultivar (Peter Pears) resulted from corms soaked in EMS solution at either 0.1 or $0.2 \%$ concentrations. Corms of Nova Lux cultivar treated with $0.2 \%$ EMS solution also gave a height closely near to those of the previous treatments in the second season.

The greatest number of leaves/plant (as shown in Table, 1) was obtained in the two seasons by soaking corms in $0.1 \%$ colchicine solution for 24 hours $(8$ leaves/plant in both seasons). Colchicine at $0.1 \%$ for 48 hours and EMS up to $0.3 \%$ concentration treatments registered also a higher number of leaves, but it was to some extent lesser than that of soaking in colchicine for 24 hours treatment. Cultivars of Eurovision and Nova Lux gave higher number of leaves than cv. Peter Pears in the two seasons. However, the highest number of leaves/plant for the three studied cultivars was ascribed to treating with $0.1 \%$ colchicine for 24 hours in the two seasons. A similar trend was also recorded by EMS at $0.1,0.2$ and 0.3 levels, as well as colchicine for 48 hours in both seasons.

Reduction of growth, especially at higher concentrations or soaking for long duration may be attributed to the high toxicity of the used mutagens and its direct role on depression the biosynthesis of some amino acids, such as L-cysteine and O-acetyl serine in the meristematic cells (Inter Net site 1,2000 ), whereas increasing mean number of branches or leaves may refer to the ability of these mutagens to overcome the apical dominance and hence, stimulate the lateral buds to develop into new leafy shoots (Vainola, 2000). These findings however are in accordance with those observed by Endo et al. (1997) on chrysanthemum, Han et al. (1999) on lilium, Berenschat et al. (2008) on petunia, Xing et al. (2011) on Catharanthus roseus and Wand and Lei (2012) on Clivia miniata.

\section{2- Corm production:}

Data presented in Table (2) exhibit that colchicine at $0.1 \%$ for 24 hours. resulted the widest diameter $(\mathrm{cm})$ and heaviest fresh weight (g) of the new corms, as well as the highest number of cormels/plant comparing with control and other treatments in the two seasons, except for EMS treatment at $0.1 \%$ concentration which gave number of cormels in the first season closely near to that of the previous best treatment. Concerning the effect of cultivars, Peter Pears cultivar gave the largest diameter in both seasons in comparison to Eurovision and Nova Lux cultivars. Whereas cv. Eurovision registered heavier fresh weight and higher number of cormels than the other two cultivars in both seasons. Regarding the interaction treatments, it could be noticed that colchicine solution at $0.1 \%$ for 24 hours was the best treatment for getting the best diameter and fresh weight of the new formed corms in the three studied cultivars, while the highest number of cormels/plant in the two seasons was scored for Eurovision and Nova Lux cvs. by soaking the corms in $0.1 \%$ colchicine solution for 24 hours, but for Peter Pears cultivar that was gained by soaking in EMS solution at $0.1 \%$ level.

These results could be interpreted and discussed as done before in case of vegetative growth characters. 
H.F. El-Tayeb

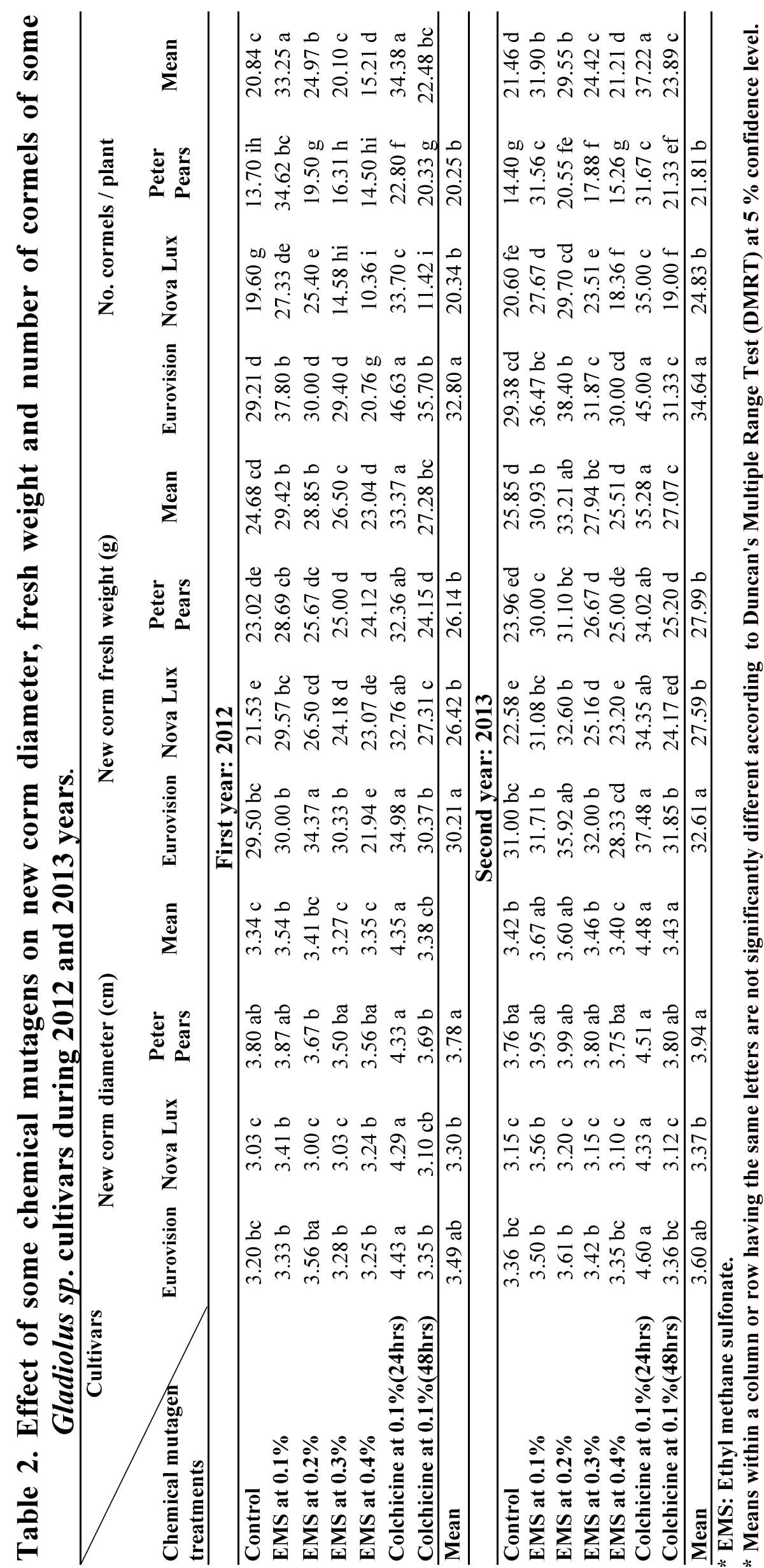


However parallel observations were also obtained by El-Meligy (1981) and Misra and Bajpai (1983) on gladiolus, Han et al. (1999) on Asiatic hybrid lily and Silva et al. (2000) on the proto corm-like bodies of Cattleya intermedia.

According to the aforementioned results, it can be summarized that soaking corms of the three studied cultivars of gladiolus in $0.1 \%$ colchicine solution for 24 hours is one of the best methods for improving some morphological traits and corm production.

\section{ACKNOWLEDGEMENT}

The author wish to express his sincere gratitude to Prof. Dr. Sayed M. Shahin, Head Researches Emeritus, Hort. Res. Inst, ARC for his guidance and helpful suggestions during preparing this manuscript

\section{REFERENCES}

Berenschot, A.S.; Zucchi, M.I.; TulmannNeto, A. and Quecini, V. (2008). Mutagenesis in Petunia hybrida Vilm and isolation of a novel morphological mutant. Braz.J. Plant Physiol., 20(2):95-103.

Dhakshanamoorthy, D.; Selvaraj, R. and Chidambaram, A. (2010). Physical and chemical mutagenesis in Jatropha curcas to induce variability in seeds germination, growth and yield traits. Rom. J. Biol., 55(2):113-125.

Duncan, D. B. (1955). Multiple range and multiple F-test. J. Biometrics, 11:1-42.

El-Meligy, M.M. (1981). Morphological studies on the effect of colchicines on the flowering and corm production of gladiolus. A. Effect on growth and corm production. Agric. Res. Rev., 59(3):313324.

Endo, M.; Kim, J. and Indanda, I. (1997). Production and characteristics of chromosome doubled plants of small flowered garden Chrysanthemum by colchicine treatment. J. Japanese Soci. Hort. Sci., 65:825-833.
Han, D.; Nimii, Y. and Nakano, M. (1999). Production of doubled haploid plants through colchicines treatment in the Asiatic hybrid lily "Conneticut King". J. Japanese Soc. Hort. Sci., 68:979-983.

Kannan, M.; Sathiyamurthy, V.A. and Sanker, V. (2002). Mutagenetic studies on Jasminum sambac. Proc. of the National Sym. on Indian Floriculture in the New Millennium, Lal Bagh., Bangalore, 25-27 Feb.: 209-2011.

Latado, R.R.; Adams, A.H. and Neto, A.T. (2004). In vitro mutation of chrysanthemum with EMS in immature floral pedicels. Plant Cell, Tissue and Organ Culture, 77(1):103-106.

Mead, R.; Curnow, R.N. and Harted, A.M. (1993). Statistical Methods in Agriculture and Experimental Biology, $2^{\text {nd }}$ Ed., Chapman and Hall Ltd., London, 335 pp.

Misra, R.L. and Bajpai, B.N. (1983). Mutational studies in Gladiolus. I. Effect of physical and chemical mutagens on sprouting and survival of corms. Haryana J. Hort. Sci., 12(1/2):1-6.

Padmadevi, K. and Jawaharlal, M. (2011). Induction of in vitro mutation in chrysanthemum ray florets var. Ravi Kiran using gamma rays and EMS. Floriculture and Ornam. Biotech., Global Science Books, India, pp.74-77.

SAS Institute (1994). SAS/STAT User's Statistics. Vers. 6.04, $4^{\text {th }}$ Ed., SAS Institute Inc., Cary; N.C., USA.

Sayed, S. Sawsan; Youssef, M.A. Hanan and Youssef, E.M.A. (2007). Influence of colchicine and sodium azide treatments on micropropagability and biochemical constituents of Solidago altissima Gary var. "Tara" explants in vitro. J. Bio. Chem. and Environ. Sci., 2(2): 257-276.

Schiva, T.; Ruffoni, B. and Vaccarino, R. (1984). Variabilita genetic indottada agentic chimici (EMS) su Gebera jamesonii hybrida, H. Bolus. Ann. $1^{\text {st }}$ Sper. Floric., Sanremo, VO1. XV(1):2971. 


\section{H.F. El-Tayeb}

Silva, P.A.; Jacques, S.C. and Zanettini, M.H. (2000). Induction and identification of polyploids in lindl (orchid cease) by in vitro technique. 1. Cattleya intermedia. Sciencia Rural, Santa Maria, 30(1):405111.

Vainola, A. (2000). Polypolinization and early screaming of Rhododendron hybrid. Euphytica, 122:239-244.

Wang, C. and Lei, J. (2012). In vitro induction of tetraploids from immature embryos through colchicine treatments in Clivia miniata. African J. Agric. Res., 7(25):3712-3718.

Wikipedia (2013). Ethyl methane sulfonate (EMS). http://en.wikipedia.org/wiki/Ethyl methanesulfonate.

Wikipedia (2014). Colchicine. http://en.wikipedia.org/wiki/Colchicine.
Wu, H.; He, Y.; Bi, Y. and Zhu, Y. (2007). Diploid female gametes induced by colchicine in Oriental lilies. Scientia Hort., 114:50-53.

Xing, S.; Guo, X.; Wang, Q.; Pan, Q.; Tian, Y.; Liu, P.; Zhao, J. and Tang, K. (2011). Induction and identification of tetraploids from seed-derived explants through colchicine treatments in Catharanthus roseus. J.Biomedicine and Biotech., 2011:10-20.

Yi, F. and Traore, S. (2011). In vitro mutation induction of Saintpaulia using EMS. Hortscience, 46(7):981-984.

Youssef, M.A. Hanan (2003). Induction of Mutations and Variations by Using Mutagens on Some Indoor Plants. Ph.D. Thesis, Fac. Agric., Moshtohor, Zagazig Univ., Egypt.

تأثير بعض المطفرات الكيميائية على الصفات الظاهرية و إنتاج الكورمات لبعض أصناف الجلاديولس

$$
\text { قسم بحوث الحدائق النباتية، معهد البحوث البساتتين (فرع أنطونيادس)، الأسكندرية، مصر. }
$$

أجريت تجربتا أصص بمشتل حديقة انطونيادس النباتية، قسم بحوث الحدائق النباتية، معهد بحوث البساتين،

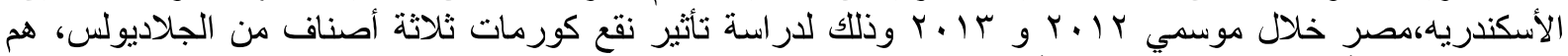
( Eurovision

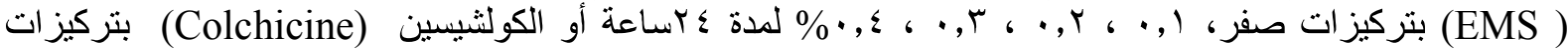

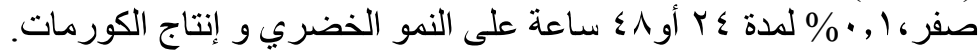

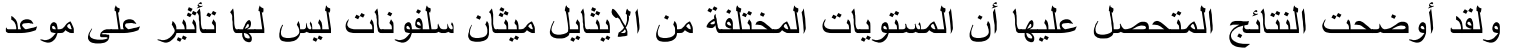

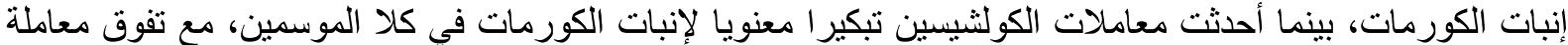

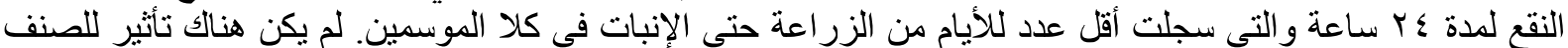

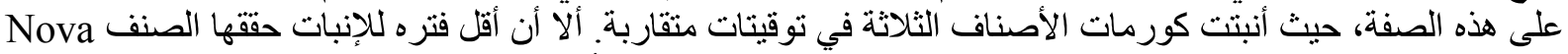

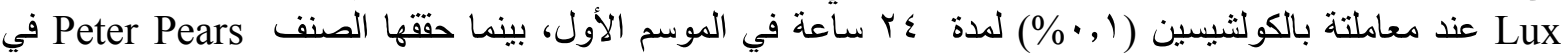

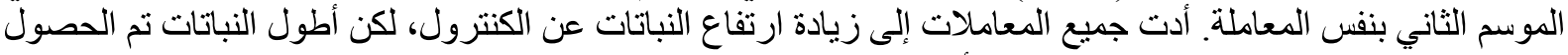

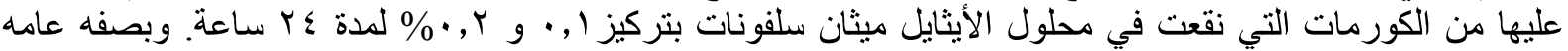

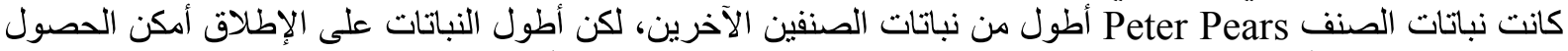

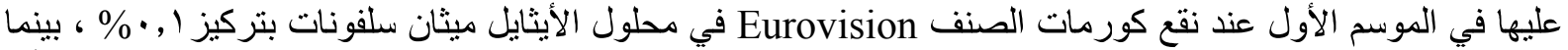

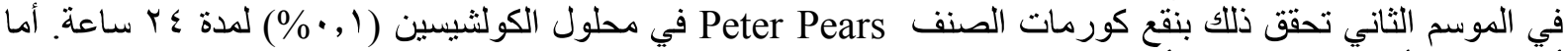

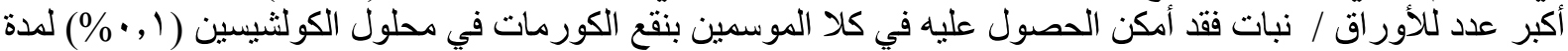

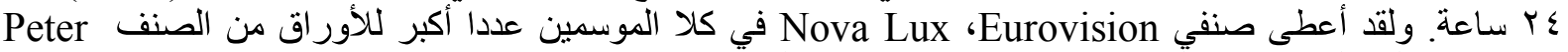
Pears، إلا أن أكبر عدد للأُوراق على الإطلاق حققته الأصناف الثلاثة في كلا الموسمين كان عند معاملتها بمحلول

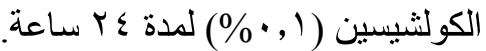




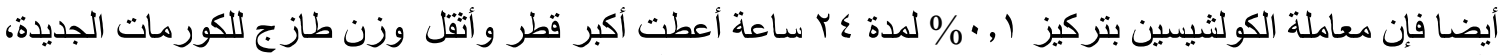

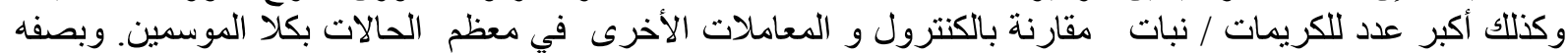

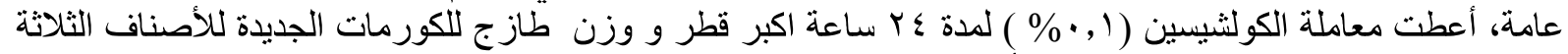

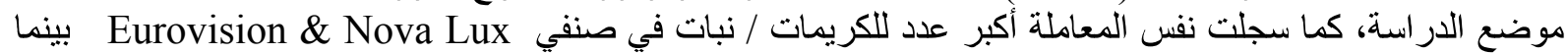

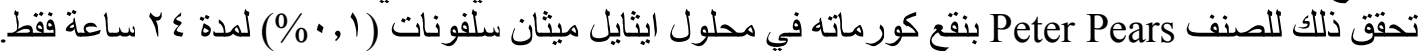

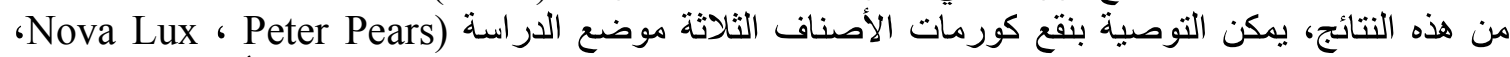

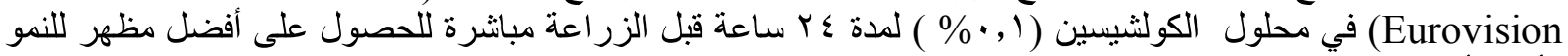

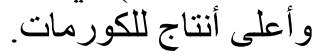

